\title{
Deflection of Complex Geometry Cutting Tools
}

Ondřej Bílek ${ }^{1}$, Pavel Smetka ${ }^{1}$, Jitka Bad'urová ${ }^{2}$

${ }^{1}$ Department of Production Engineering, Faculty of Technology, Tomas Bata University in Zlín, Vavrečkova 275 , 76001 Zlín. Czech Republic. E-mail: bilek@utb.cz; p_smetka@ft.utb.cz

${ }^{2}$ Department of Physics and Materials Engineering, Tomas Bata University in Zlín, Vavrečkova 275, 76001 Zlín. Czech Republic. E-mail: badurova@ft.utb.cz

Deflection of cutting tools under the action of cutting forces has a significant influence on the error of machined surface and the stability of cutting process. Considering the complex geometric structure of cutting tools lead to higher calculation accuracy of the tool deflection analysis. Therefore, CAD models of double-sided solid ball end mill and helical drill bit was created in this study. The impact of tool material and clamping of the tool under the influence of cutting forces individually in three axes was obtained via finite element analysis. An error of the numerical model was less than $\mathbf{7 . 2 \%}$ and has been validated by analytical calculation. Geometric errors in the case of die and mold manufacturing are provided below or close to $0.02 \mathrm{~mm}$. However, due to the force effect of the cutting process it is not recommended to use HSS tools as the analysis confirmed. Stiffness of sintered carbide tools was more than doubled.

Keywords: Deflection, Clamping, CAD, FEM, Solid Ball End Mill.

\section{References}

[1] BEŇO, J., MAŇKOVÁ, I., IŽOL, P. VRABEL', M. (2016). An approach to the evaluation of multivariate data during ball end milling free-form surface fragments. In: Measurement: Journal of the International Measurement Confederation, Vol. 84, pp. 7-20. Elsevier BV. Netherlands.

[2] CEPOVA, L., SOKOVA, D., MALOTOVA, S., GAPINSKI, B., CEP, R. (2016). Evaluation of cutting forces and surface roughness after machining of selected materials. In: Manufacturing Technology, Vol. 16, No. 1, pp. 4548. J. E. Purkyne University in Usti n. Labem. Czech Republic.

[3] FIALA, Z., JAROS, A., SEDLAK, J., KOLAR, L., BLAZKOVA, V. (2015), Effect of spindle unit extrusion on stability of machining process. In: Manufacturing Technology, Vol. 15, No. 3, pp. 329-333. J. E. Purkyne University in Usti n. Labem. Czech Republic.

[4] LOPEZ DE LACALLE, L.N., LAMIKIZ, A., SANCHEZ, J.A., SALGADO, M.A. (2004). Effects of tool deflection in the high-speed milling of inclined surfaces. In: The International Journal of Advanced Manufacturing Technology, Vol. 24, No. 9-10, pp. 621-631. Springer Heidelberg. Germany.

[5] MATRAS, A., PLAZA, M. (2016). The FEM simulation of the thin walled aircraft engine corpus deformation during milling. In: Proceedings of SPIE - The International Society for Optical Engineering (R. Romaniuk, (Ed.)), pp. 100310B. Wilga. Poland.

[6] MIKÓ, B. (2015). Study on tolerance of shape and orientation in case of shoulder milling. In: Development in machining technology, Vol. 5, pp. 136-150. Cracow University of Technology. Cracow.

[7] MIKÓ, B., PALÁSTI-KOVÁCS, B., SIPOS, S., DRÉGELYI-KISS, Á. (2015) Investigation of cutting edge preparation process in drilling. In: International Journal of Machining and Machinability of Materials, Vol. 17, No. 6, pp 529-542. Inderscience Publishers, United Kingdom.

[8] OSIČKA, K., FIŠEROVÁ, Z., OTOUPALÍK, J. (2015). Influence of cutting tool overhangs at machining of hardened steels. In: Manufacturing Technology. 2015. Vol. 15, No. 2. pp. 188-191. J. E. Purkyne University in Usti $n$. Labem. Czech Republic.

[9] VARGA, G., DUDAS, I. (2004). Modelling and examinations of dry machining processes. In: Proceedings of the IASTED International Conference on Modelling, Simulation, and Optimization. Kauai, HI. United States.

[10] WANG, L., CHEN, Z. C. (2014). A new CAD/CAM/CAE integration approach to predicting tool deflection of end mills. In: International Journal of Advanced Manufacturing Technology. Vol. 72, No. 9-12, pp. 1677-1686. Springer-Verlag. London.

[11] WOJCIECHOWSKI, S., CHWALCZUK, T., TWARDOWSKI, P., KROLCZYK, G.M. (2015). Modeling of cutter displacements during ball end milling of inclined surfaces. In: Archives of Civil and Mechanical Engineering, Vol. 15, No. 4, pp. 798-805. Politechnika Wrocławska. Poland. 
[12] XU, A.-P., QU, Y.-X., ZHANG, D.-W., HUANG, T. (2003) Simulation and experimental investigation of the end milling process considering the cutter flexibility. In: International Journal of Machine Tools and Manufacture, Vol. 43, No. 3, pp. 283-292. Elsevier Science Ltd. Netherlands.

[13] XU, J., GU, L., LUO, S. (2014). Dynamic analysis for high-speed cutters of five-axis CNC milling machine. In: Manufacturing Technology, Vol. 14, No. 4, pp. 643-650. Purkyne University in Usti n. Labem. Czech Republic.

[14] ZĘBALA, W. (2012) Tool stiffness influence on the chosen physical parameters of the milling process. In: Bulletin of the Polish Academy of Sciences: Technical Sciences, Vol. 60, No. 3, pp. 597-604. DE GRUYTER OPEN. Poland.

[15] ZĘBALA, W. (2015). Tool deflection in the milling of titanium alloy: case study. In: Proceedings of SPIE - The International Society for Optical Engineering. pp. 96624Q. SPIE. USA.

[16] ZEBALA, W. (2016). The Influence of Tool Stiffness on the Dimensional Accuracy in Titanium Alloy Milling. In: Key Engineering Materials, Vol. 686, No. 1, pp. 108-113. TTP. Switzerland.

[17] ZEROUDI, N., FONTAINE, M. (2015). Prediction of tool deflection and tool path compensation in ball-end milling. In: Journal of Intelligent Manufacturing, Vol. 26, No. 3, pp. 425-445. Springer US. USA.

Copyright (C) 2017. Published by Manufacturing Technology. All rights reserved. 